\title{
Effects of an antimicrobial stewardship intervention on perioperative antibiotic prophylaxis in pediatrics
}

\author{
Daniele Donà ${ }^{1,2}$, Dora Luise ${ }^{3,7^{*}}$ (D), Enrico La Pergola ${ }^{4}$, Genni Montemezzo ${ }^{4}$, Annachiara Frigo ${ }^{5}$, Rebecca Lundin², \\ Theoklis Zaoutis ${ }^{6}$, Piergiorgio Gamba ${ }^{4}$ and Carlo Giaquinto ${ }^{1,2}$
}

\begin{abstract}
Purpose: This study aims to determine the effectiveness of an Antimicrobial Stewardship Program based on a Clinical Pathway (CP) to improve appropriateness in perioperative antibiotic prophylaxis (PAP).

Materials and methods: This pre-post quasi-experimental study was conducted in a 12 month period (six months before and six months after CP implementation), in a tertiary Pediatric Surgical Centre. All patients from 1 month to 15 years of age receiving one or more surgical procedures were eligible for inclusion. PAP was defined appropriate according to clinical practice guidelines.
\end{abstract}

Results: Seven hundred sixty-six children were included in the study, 394 in pre-intervention and 372 in postintervention. After CP implementation, there was an increase in appropriate PAP administration, as well as in the selection of the appropriate antibiotic for prophylaxis, both for monotherapy $(p=0.02)$ and combination therapy $(p=0.004)$. Even the duration of prophylaxis decreased during the post-intervention period, with an increase of correct PAP discontinuation from 45.1 to $66.7 \%(p<0.001)$. Despite the greater use of narrowspectrum antibiotic for fewer days, there was no increase in treatment failures (10/394 (2.5\%) pre vs 7/372 (1. 9\%) post, $p=0.54$.

Conclusions: CPs can be a useful tool to improve the choice of antibiotic and the duration of PAP in pediatric patients.

Keywords: Perioperative antimicrobial prophylaxis, Antimicrobial stewardship, Clinical pathway, Pediatric surgery

\section{Background}

Surgical Site Infection (SSI) is the second most common healthcare-associated infection [1] and Centres for Disease Control and Prevention (CDC) showed that it complicates approximately $5 \%$ [2] of surgical operations each year.

SSIs account for more than 16\% [3] in adults and 17$18 \%[4,5]$ in children of all hospital-acquired infections recorded in the National Healthcare Surveillance Safety Network of the Centres for Disease Control and

\footnotetext{
* Correspondence: luise.dora@gmail.com

${ }^{3}$ Infectious and Tropical Diseases Department, University Hospital of Verona, Verona, Italy

${ }^{7}$ Padova, Italy

Full list of author information is available at the end of the article
}

Prevention (CDC) and 38\% of nosocomial infections in surgical patients [2].

So far, only four studies focused on antimicrobial stewardship projects (ASP) for perioperative prophylaxis in children. Three of these studies showed an improvement of antimicrobial prescriptions after the implementation of perioperative guidelines $[3,6,7]$, while Putnam et al. reported no improvement despite multiple interventions, such as creation of a targeted preincisional checklist and of a computerized order entry module [8]. These few data limit the conclusions that can be drawn about efficacy and safety of these strategies and represents important space for improvement for ASP in pediatric surgical prophylaxis on both side of Atlantic [3, 6-8].

(c) The Author(s). 2019 Open Access This article is distributed under the terms of the Creative Commons Attribution 4.0 International License (http://creativecommons.org/licenses/by/4.0/), which permits unrestricted use, distribution, and reproduction in any medium, provided you give appropriate credit to the original author(s) and the source, provide a link to the Creative Commons license, and indicate if changes were made. The Creative Commons Public Domain Dedication waiver (http://creativecommons.org/publicdomain/zero/1.0/) applies to the data made available in this article, unless otherwise stated. 
The aim of this study is to determine the effectiveness of an ASP based on a Clinical Pathway (CP) to improve the adherence to perioperative antibiotic prophylaxis (PAP) guidelines [9] in a Pediatric Surgical Centre. A secondary aim is to evaluate the effect $\mathrm{CP}$ implementation on SSIs. To our knowledge, no specific guidelines on antimicrobial prophylaxis in pediatric surgery have been published so far, hence our CP has been developed according to the main guidelines for adult patients, that were published jointly by the American Society of Health-System Pharmacists (ASHP), the Infectious Diseases Society of America (IDSA), the Surgical Infection Society (SIS), and the Society for Healthcare Epidemiology of America (SHEA) in 2013 [9].

\section{Materials and methods}

\section{Study design}

This is a pre-post quasi-experimental study to assess the changes in PAP appropriateness during a 6-month period preceding $\mathrm{CP}$ implementation (per-intervention, from 1 February 2016 to 31 July 2016) and during the six months after CP implementation (post intervention, from 1 February 2017 to 31 July 2017).

The study was set at the Surgical Paediatric Unit of the Department for Women and Children Health at Padua University Hospital.

\section{Clinical pathway}

The clinical pathway was developed by a multidisciplinary group (paediatric infectious disease, microbiology and paediatric surgery) based on the most important international clinical guidelines [9], considering our local microbiology data, and with the supervision of the paediatric infectious diseases team of Philadelphia Children's Hospital (Figs. 1, 2, 3, and 4).

The CP details all the steps needed to administer a correct PAP.

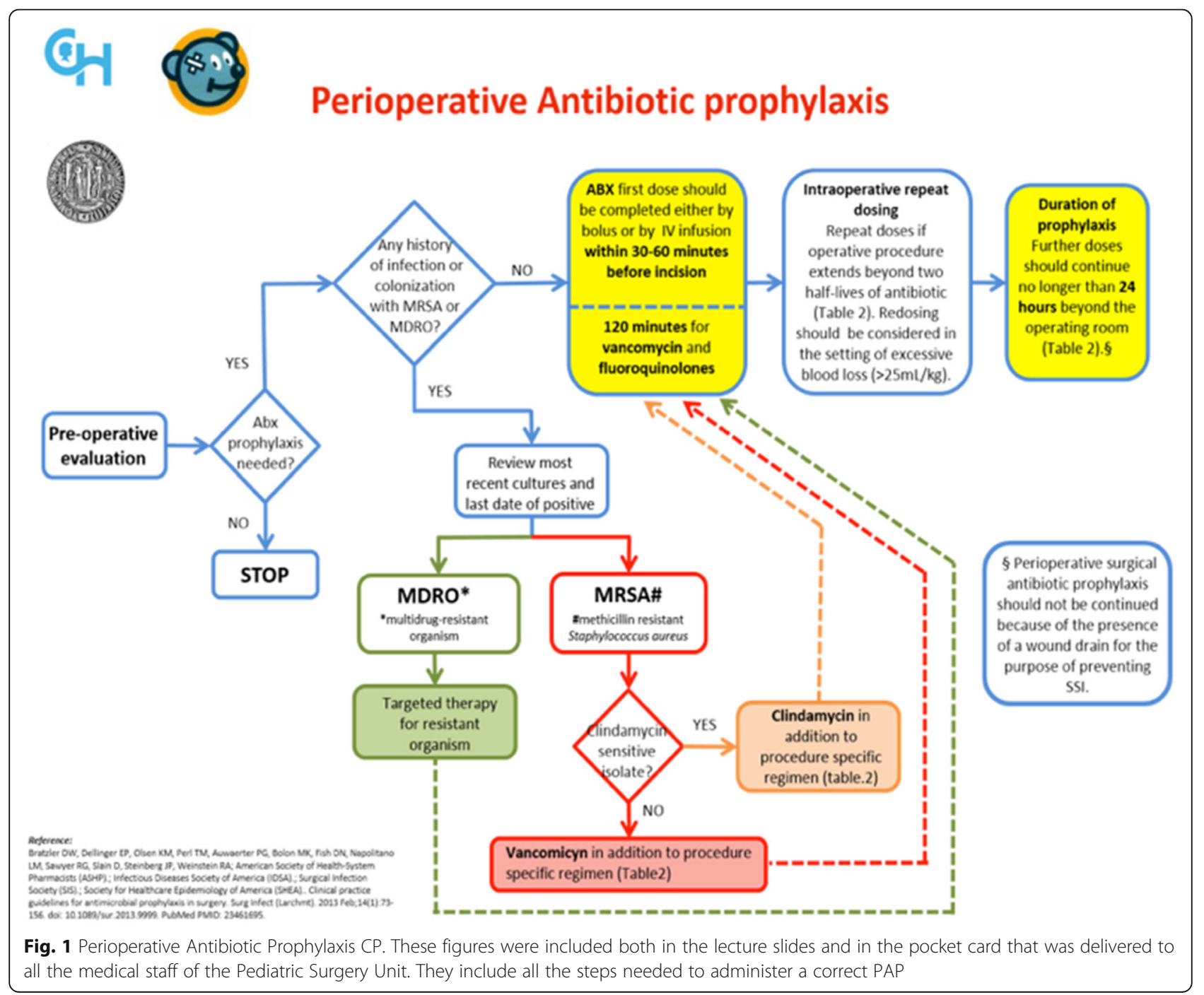




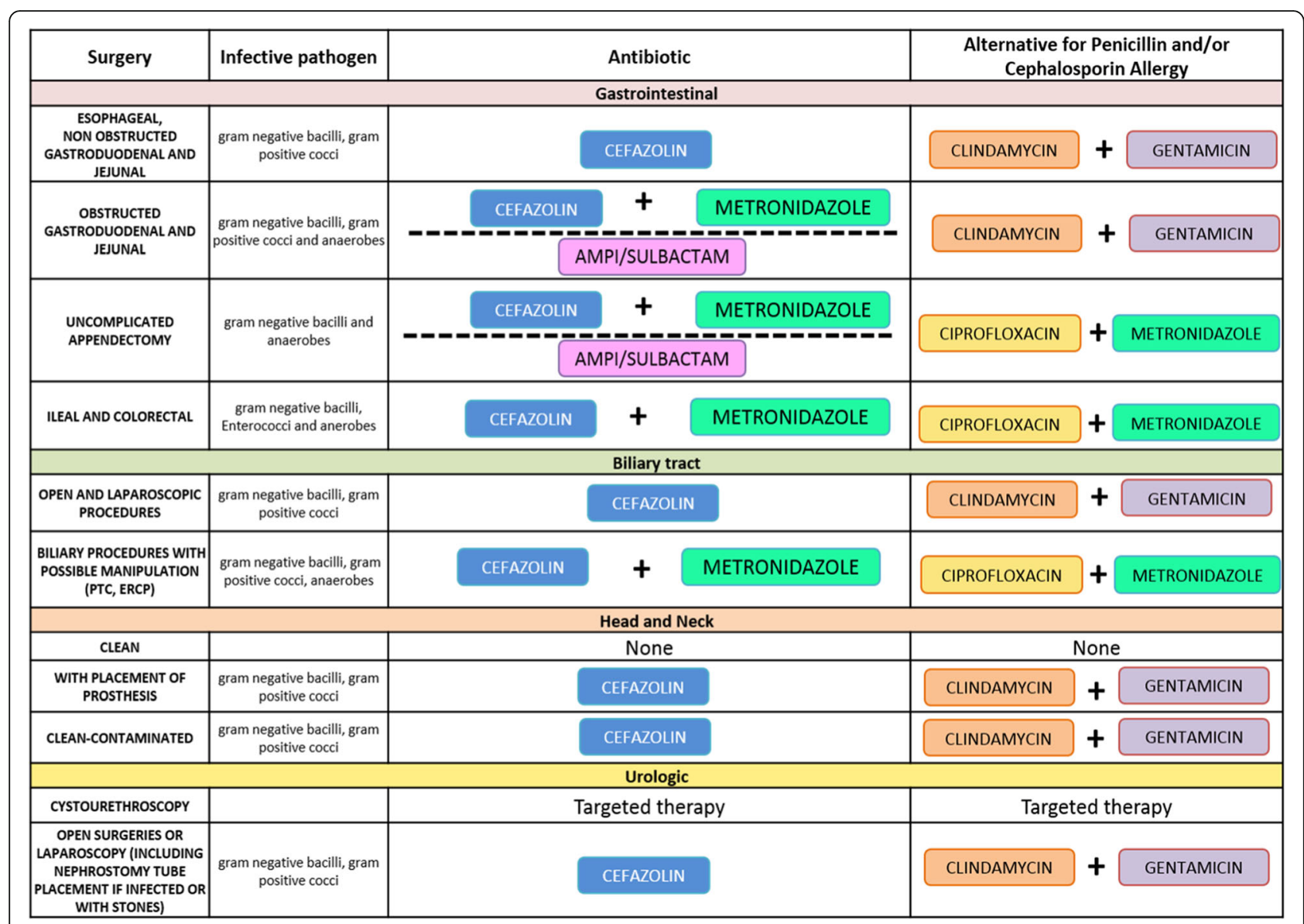

Fig. 2 Perioperative Antibiotic Prophylaxis CP

The first step is to consider the surgical procedure (type, site and risk for developing SSIs), and consequently to decide whether to give PAP to the patient. The second step is to consider the patient's medical history of colonization by multi-drug resistant organisms (MDROs). If the medical history is negative for MDRO, an empiric antibiotic regimen should be administered according to the type of surgical procedure. Otherwise, the prophylaxis will be targeted to the specific MDRO. Dose and duration of administration must follow the indications detailed in the $\mathrm{CP}$.

The drug of choice for all surgical interventions is a first-generation cephalosporin alone. The association with metronidazole is recommended for surgical procedure with high risk for anaerobic bacteria contamination. Other molecules as clindamycin, gentamicin and ciprofloxacin should be given only to patients with proven allergy to beta-lactams antibiotic. Antibiotic first dose should be administered within 30-60 min before incision, with the exception of vancomycin and ciprofloxacin, that should be given $120 \mathrm{~min}$ before the incision, due to their longer half-life. An intraoperative re-dosing should be performed if the procedure extends beyond two half-lives of the antibiotic and it should be considered in the setting of excessive blood loss $(>25 \mathrm{~mL} / \mathrm{kg})$. The PAP should be discontinued within $24 \mathrm{~h}$ after the end of the procedure, and should not be extended longer in presence of wound drains or prosthetic implants, according to the work of Wilson and colleagues [10].

Specific recommendations for antibiotic dosages are included in the CP.

\section{Intervention}

On 31 January 2017 the CP for PAP was implemented.

On the same day, an educational lecture was presented to all the medical staff of the Pediatric Surgery Unit. This meeting provided a review of the clinical guidelines for PAP and the potential benefits of a correct PAP, discussed the rationale for the guideline recommendations and highlighted situations where local practice in the Pediatric Surgery Unit diverged from guideline recommendations.

Following the lecture, a pocket card containing the $\mathrm{CP}$ was delivered to all participants and, on the same day, to all other physicians and residents who were unable to attend the seminar. 
CEFAZOLIN: Maximum concentration - $100 \mathrm{mg} / \mathrm{ml}$; (IVP) infuse over $3-5$ minutes.

\begin{tabular}{|c|c|c|c|}
\hline Age/Weight & Dosing & $\begin{array}{c}\text { Time for Redose } \\
\text { (OR only) }\end{array}$ & Number of Postop Doses \\
\hline Neonates $\leq 7$ days or $\leq 2 \mathrm{Kg}$ & $20 \mathrm{mg} / \mathrm{kg} /$ dose & 8 hours & 2 \\
\hline Neonates $>7$ days or $>2 \mathrm{Kg}$ & $20 \mathrm{mg} / \mathrm{kg} /$ dose & 4 hours & 3 \\
\hline $\begin{array}{c}\text { Infants }>1 \text { month, children, } \\
\text { adolescents and adults }\end{array}$ & $\begin{array}{c}30 \mathrm{mg} / \mathrm{kg} / \text { dose } \\
\text { (maximum } 2 \text { grams) }\end{array}$ & 4 hours & 3 \\
\hline
\end{tabular}

METRONIDAZOLE: Maximum concentration $-5 \mathrm{mg} / \mathrm{ml}$; (IVSS) infuse over 30 minutes.

\begin{tabular}{|c|c|c|c|}
\hline Age/Weight & Dosing & Time for Redose (OR only) & Number of Postop Doses \\
\hline $\begin{array}{c}\text { Neonates 0-4 weeks AND }<1.2 \mathrm{~kg}, \\
\text { Neonates } \leq 7 \text { days AND } 1.2-2 \mathrm{Kg}\end{array}$ & $7.5 \mathrm{mg} / \mathrm{kg} /$ dose & No redose & $\begin{array}{c}\text { No additional dose } \\
\text { required }\end{array}$ \\
\hline $\begin{array}{c}\text { Neonates } \leq 7 \text { days AND }>2 \mathrm{Kg}, \\
\text { Neonates }>7 \text { days AND } 1.2-2 \mathrm{~kg}\end{array}$ & $7.5 \mathrm{mg} / \mathrm{kg} /$ dose & 12 hours & 2 \\
\hline Neonates $>7$ days AND $>2 \mathrm{~kg}$ & $15 \mathrm{mg} / \mathrm{kg} /$ dose & 12 hours & 2 \\
\hline $\begin{array}{c}\text { Infants, children, adolescents and } \\
\text { adults }\end{array}$ & $\begin{array}{c}7.5 \mathrm{mg} / \mathrm{kg} / \text { dose }(\text { maximum } \\
\text { dose } 500 \mathrm{mg})\end{array}$ & 6 hours \\
\hline Adults (colorectal) & $\begin{array}{c}15 \mathrm{mg} / \mathrm{kg} / \text { dose }(\text { maximum } \\
\text { dose } 1 \text { gram) }\end{array}$ & $\begin{array}{c}6 \text { hours with } 7.5 \\
\mathrm{mg} / \mathrm{kg} / \text { dose }(\text { maximum } \\
\text { dose } 500 \mathrm{mg})\end{array}$ & 4 \\
\hline
\end{tabular}

AMPICILLIN/SULBACTAM: Maximum concentration $-30 \mathrm{mg} / \mathrm{ml}$;

\begin{tabular}{|c|c|c|c|}
\hline & Dosing & Time for Redose (OR only) & Number of Postop Doses \\
\hline Neonates $<14$ days & $50 \mathrm{mg} / \mathrm{kg} /$ dose & 8 hours & 2 \\
\hline Neonates $\geq 14$ days & $50 \mathrm{mg} / \mathrm{kg} /$ dose & 8 hours & 2 \\
\hline $\begin{array}{c}\text { Infants }>1 \text { month, children, } \\
\text { adolescent and adults }\end{array}$ & $\begin{array}{c}50 \mathrm{mg} / \mathrm{kg} / \text { dose } \\
\text { (maximum dose } 2 \text { grams) }\end{array}$ & 4 hours & 2 \\
\hline
\end{tabular}

CLINDAMYCIN: Maximum concentration $-20 \mathrm{mg} / \mathrm{ml}$; (IVSS) infuse over at least $10-60$ minutes, at a rate not to exceed $30 \mathrm{mg} / \mathrm{minute}$

\begin{tabular}{|c|c|c|c|}
\hline & Dosing & Time for Redose (OR only) & Number of Postop Doses \\
\hline Age/Weight & $5 \mathrm{mg} / \mathrm{kg} /$ dose & 12 hours & 2 \\
\hline Neonates $\leq 7$ days or $\leq 2 \mathrm{Kg}$ & $5 \mathrm{mg} / \mathrm{kg} /$ dose & 6 hours & 6 hours \\
\hline $\begin{array}{c}\text { Infants }>1 \text { month, children, } \\
\text { adolescents and adults }\end{array}$ & $\begin{array}{c}10 \mathrm{mg} / \mathrm{kg} / \text { dose } \\
\text { (maximum } 900 \mathrm{mg} \text { ) }\end{array}$ & 3 \\
\hline
\end{tabular}

VANCOMYCIN: Maximum concentration $-5 \mathrm{mg} / \mathrm{ml}$; (IVSS) infuse over 1 hour

\begin{tabular}{|c|c|c|c|}
\hline Age/Weight & Dosing & Time for Redose (OR only) & Number of Postop Doses \\
\hline $\begin{array}{c}\text { Neonate }<7 \text { days AND 1000-2000 } \\
\text { grams, Neonate } \geq 7 \text { days AND } \\
1000 \text { grams }\end{array}$ & $15 \mathrm{mg} / \mathrm{kg} /$ dose & No redose & $\begin{array}{c}\text { No additional dose } \\
\text { required }\end{array}$ \\
\hline $\begin{array}{c}\text { Neonate }<7 \text { days AND }>2000 \\
\text { grams, Neonate } \geq 7 \text { days AND } \\
1000-2000 \text { grams }\end{array}$ & $15 \mathrm{mg} / \mathrm{kg} /$ dose & 12 hours & 2 \\
\hline $\begin{array}{c}\text { Neonates } \geq 7 \text { days AND } \geq 2000 \\
\text { grams }\end{array}$ & $15 \mathrm{mg} / \mathrm{kg} /$ dose & 8 hours & 3 \\
\hline $\begin{array}{c}\text { Infants }>1 \text { month, children } \leq 50 \mathrm{~kg} \\
\text { (maximum } 750 \mathrm{mg})\end{array}$ & 6 hours & 4 \\
\hline Children $>50 \mathrm{~kg}$ and adults & $1000 \mathrm{mg}$ & 8 hours & 3 \\
\hline
\end{tabular}

CIPROFLOXACIN: Maximum concentration $-2 \mathrm{mg} / \mathrm{ml}$; (IVSS) infuse over 1 hour.

\begin{tabular}{|c|c|c|c|}
\hline & Dosing & Time for Redose (OR only) & 2 \\
\hline Children $(\leq 40 \mathrm{~kg})$ & $\begin{array}{c}10 \mathrm{mg} / \mathrm{kg} / \mathrm{dose}(\mathrm{maximum} \\
\text { dose } 400 \mathrm{mg})\end{array}$ & 5 hours & 2 \\
\hline Adults $(>40 \mathrm{~kg})$ & $400 \mathrm{mg}$ & 8 hours & 2 \\
\hline
\end{tabular}

Fig. 3 Perioperative Antibiotic Prophylaxis CP 


\begin{tabular}{|c|c|c|c|}
\hline Age/Weight & Dosing & Time for Redose (OR only) & Number of Post op Doses \\
\hline Neonates & $4 \mathrm{mg} / \mathrm{kg} /$ dose & No redose & $\begin{array}{l}\text { No additional dose } \\
\text { required }\end{array}$ \\
\hline $\begin{array}{c}\text { Infants }>1 \text { month, children } \leq 10 \\
\text { years }\end{array}$ & $2.5 \mathrm{mg} / \mathrm{kg} /$ dose** & 6 hours* & 3 \\
\hline $\begin{array}{c}\text { Children }>10 \text { years, adolescents } \\
\text { and adults }\end{array}$ & $2.5 \mathrm{mg} / \mathrm{kg} / \mathrm{dose} \mathrm{e}^{* *}$ & 6 hours* & 3 \\
\hline
\end{tabular}

CEFTRIAXONE: Maximum concentration $-40 \mathrm{mg} / \mathrm{ml}$; (IVP) infuse over 2-4 minutes.

\begin{tabular}{|c|c|c|c|}
\hline Age/velight & Dosing & Time for Redose (OR only) & Number of Postop Doses \\
\hline Neonates & Use cefotaxime in neonate & - & - \\
\hline $\begin{array}{c}\text { Infants, children, adolescents and } \\
\text { adults }\end{array}$ & $\begin{array}{c}75 \mathrm{mg} / \mathrm{kg} / \mathrm{dose} \\
\text { (maximum dose } 2 \text { grams) }\end{array}$ & 12 hours & 1 \\
\hline
\end{tabular}

PIPERACILLIN/TAZOBACTAM: Maximum concentration $-60 \mathrm{mg} / \mathrm{ml}$ (60 mg piperacillin component); IV intermittent infusion: infuse over $20-30 \mathrm{~min}$.

\begin{tabular}{|c|c|c|c|}
\hline Age/Weight & Dosing & Time for Redose (OR only) & Number of Postop Doses \\
\hline GA $<32$ weeks and PNA $<14$ days & $\begin{array}{c}80 \mathrm{mg} / \mathrm{kg} / \mathrm{dose} \text { of } \\
\text { piperacillin component }\end{array}$ & 8 hours & 3 \\
\hline $\begin{array}{l}G A<32 \text { weeks and } P N A \geq 14 \text { days, } \\
G A \geq 32 \text { weeks and } P N A<14 \text { days }\end{array}$ & $\begin{array}{c}80 \mathrm{mg} / \mathrm{kg} / \mathrm{dose} \text { of } \\
\text { piperacillin component }\end{array}$ & 4 hours & 3 \\
\hline$G A \geq 32$ weeks and $P N A \geq 14$ days & $\begin{array}{c}100 \mathrm{mg} / \mathrm{kg} / \mathrm{dose} \text { of } \\
\text { piperacillin component }\end{array}$ & 4 hours & 3 \\
\hline Infants $>28$ days to 2 months & $\begin{array}{c}100 \mathrm{mg} / \mathrm{kg} / \mathrm{dose} \text { of } \\
\text { piperacillin component }\end{array}$ & 3 hours & 4 \\
\hline Infants $\geq 2$ months to 9 months & $\begin{array}{c}80 \mathrm{mg} / \mathrm{kg} / \mathrm{dose} \text { of } \\
\text { piperacillin component }\end{array}$ & 3 hours & 4 \\
\hline $\begin{array}{l}\text { Infants }>9 \text { months, children, } \\
\text { adolescents and adults }\end{array}$ & $\begin{array}{c}100 \mathrm{mg} / \mathrm{kg} / \mathrm{dose} \text { of } \\
\text { piperacillin component } \\
\text { (maximum dose } 3 \text { grams) }\end{array}$ & 2 hours & 4 \\
\hline
\end{tabular}

Fig. 4 Perioperative Antibiotic Prophylaxis CP

\section{Study population}

All patients aged between one month and 15 years subjected to one or more surgical procedures were eligible to be included in our study.

Exclusion criteria were: concomitant infections, ongoing antibiotic therapy, complicated abdominal infection, immunodeficiency, immunosuppressive therapy, patients who underwent neurosurgical, vascular, ORL, and ocular procedures.

\section{Data source}

All clinical, demographic, diagnostic and antimicrobial data were manually collected from electronic (Galileo system) or paper medical records. We used a password-protected REDCap ${ }^{\circ}$ data collection form and we stored them in the secure server at the University of Padua. Surgical procedures were recorded using the international classification of disease, 9th revision and clinical modification (ICD $9 \mathrm{CM}$ ).

For every patient were recorded:

1) preoperative data including gender, age, weight;
2) procedure data including type of procedure (divided for major categories, according to the ICD-9-CM), wound class (divided in Clean, Clean-Contaminated, Contaminated and Dirty/Infected, according to the CDC's classification [11]), duration of surgical procedure, urgency of procedure and length of hospital stay;

3) perioperative PAP data such as indication for PAP, administration of PAP, and, among those who received PAP, correctness of PAP (both agent and duration), correctness of antimicrobial agent, correctness of time of antibiotic discontinuing.

4) postprocedure data including date of medical evaluation for SSI.

PAP was defined appropriated only if the correct antimicrobial agent for the specific surgical procedures performed had been discontinued within $24 \mathrm{~h}$ after completion of surgery, according to clinical practice guidelines for antimicrobial prophylaxis in surgery [9].

To evaluate the effectiveness and safety of the intervention, medical records follow-up was performed to assess for SSIs within 3 months after discharge. 
Privacy was guaranteed in two ways: a unique, study-specific survey number was assigned to each patient and no personally identifying data were collected.

This study was approved by the Research Ethics Committee of Department for Woman and Child Health at the University of Padua.

\section{Data analysis}

The data were analyzed with SAS 9.4 program (SAS Institute Inc., Cary, NC, USA) for Windows.

Patient's demographic and clinical data were analyzed in a descriptive way.

Association between the two periods was performed with Chi-square test or Fisher test for qualitative variables, and with Rank-sum Wilcoxon test for quantitative variables.

We conducted stratified analyses to assess if the effectiveness of intervention was affected by the surgical characteristics such as type of procedure, urgent surgical procedure, and duration of hospital stay. Statistical significance was considered with $\mathrm{p}<0.05$.

\section{Results}

During the study period, 842 children underwent surgery. Of 430 children in pre-intervention period, 11 were excluded because admitted to an intensive care ward (PICU/NICU), 18 for a complicated abdominal infection and 7 for an ongoing infectious process. For post-intervention period population, 13 were excluded because admitted in the PICU/NICU, 13 for a complicated abdominal infection and 13 for an ongoing infectious process. Indeed, 766 children were included in the study, 394 in pre-intervention period and 372 in post-intervention period.

The two populations were similar in terms of sex and age, with an overall female predominance.

Baseline patient and procedure characteristics in preand post-intervention periods are displayed in Table 1.

No difference between the different wound classes was reported between the two study populations: clean wounds were $300(76.1 \%)$ in pre- and 301 (80.9\%) in post-, clean-contaminated wounds were $63(16.0 \%)$ in pre- and $52(14.0 \%)$ in post- and contaminated wounds were $31(7.9 \%)$ in pre- and $19(8.4 \%)$ in post-.

No significant difference in the type of surgical procedures was reported between the pre- and post-intervention period, as 184/394 (46.7\%) and 153/ $372(41.1 \%)$ patients received a PAP during pre- and post-intervention period respectively (Table 2). In

Table 1 Patients' main characteristics (gender, age, weight) and preoperative data (wound class, type of procedure) pre- and postintervention periods

\begin{tabular}{|c|c|c|}
\hline Patient's characteristics & $\begin{array}{l}\text { Pre-intervention } \\
(n=394)\end{array}$ & $\begin{array}{l}\text { Post-intervention } \\
(n=372)\end{array}$ \\
\hline \multicolumn{3}{|l|}{ Gender } \\
\hline Male & $122(31 \%)$ & $111(29 \%)$ \\
\hline Female & $272(69 \%)$ & 267 (70\%) \\
\hline Median age (min-max) & $5(0-17)$ & $5(0-17)$ \\
\hline Body weight (kg) & $20(2.3-74)$ & $19(2.1-72)$ \\
\hline \multicolumn{3}{|l|}{ Wound class } \\
\hline Clean (C) & $300(76.1 \%)$ & $301(80.9 \%)$ \\
\hline Clean contaminated (CC) & $63(16 \%)$ & $52(14 \%)$ \\
\hline Contaminated (CO) & $31(7.9 \%)$ & $19(5.1 \%)$ \\
\hline Dirty-infected (D) & $0(0 \%)$ & $0(0 \%)$ \\
\hline \multicolumn{3}{|l|}{ Type of procedure } \\
\hline Appendectomy & $24(6.1 \%)$ & $21(5.7 \%)$ \\
\hline Gastrointestinal/liver-biliary tract & $42(10.7 \%)$ & $31(8.3 \%)$ \\
\hline Head and neck & $53(13.5 \%)$ & $71(19.1 \%)$ \\
\hline Inguinal/scrotum & 69 (17.5\%) & $57(15.3 \%)$ \\
\hline Pediatric Gynaecology & $6(1.5 \%)$ & $9(2.4 \%)$ \\
\hline Skin/soft tissue & $44(11.2 \%)$ & $30(8.1 \%)$ \\
\hline Umbilical hernia/abdominal wall hernia & 75 (19\%) & 74 (19.9\%) \\
\hline Thoracic & $16(4 \%)$ & $28(7.5 \%)$ \\
\hline Urologic & $17(4.2 \%)$ & $12(3.2 \%)$ \\
\hline Other & 49 (12.3\%) & 39 (10.5\%) \\
\hline
\end{tabular}


Table 2 Comparison between PAP administration and correct indication in pre- and post-intervention period

\begin{tabular}{llll}
\hline & $\begin{array}{l}\text { Pre-intervention } \\
(\mathrm{n}=394)\end{array}$ & $\begin{array}{l}\text { Post-intervention } \\
(\mathrm{n}=372)\end{array}$ & $\mathrm{p}$-value \\
\hline Administration of PAP & & $153(41.1 \%)$ & 0.12 \\
Yes & $184(46.7 \%)$ & $219(58.9 \%)$ & 0.12 \\
No & $210(53.3 \%)$ & $\mathrm{n}=153$ & $132(86.3 \%)$ \\
Correct indication for PAPa & $\mathrm{n}=184$ & $21(13.7 \%)$ & 0.4 \\
Yes & $152(82.6 \%)$ & 0.4 \\
No & $32(17.4 \%)$ &
\end{tabular}

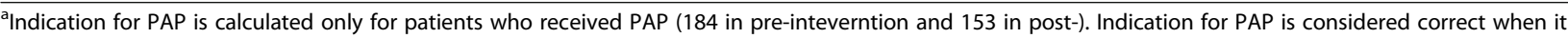
follows the guidelines' recommendations

addition, the number of patients receiving PAP according to the guidelines indications increased from 152/184 in pre- $(82.6 \%)$ to $132 / 153$ in post- $(86.3 \%)$, even though the difference was not statistically significant ( $\mathrm{p}$ value 0.4) (Table 2).

In the post-intervention period, there was an increase of correct PAP administration with 90/184 (48.9\%) in pre- versus $93 / 153(60.0 \%)$ in post-intervention period $(\mathrm{p}=0.03)$ (Table 3$)$.

In the post-intervention period, there was an increase of cefazolin use from 78.8 to $87.0 \%(\mathrm{p}=0.0001)$ with a decrease of ampicillin/sulbactam from 20.1 to $5.4 \%$ ( $\mathrm{p}=$ 0.003) as suggested by the CPs (Table 3 ).

Indeed, we found that the selection of the appropriate antibiotic for prophylaxis improved in the post-intervention period, both for monotherapy from 81.0 to $91.9 \%(\mathrm{p}=0.02)$ and combination therapy from $65.9 \%)$ to $100 \%(\mathrm{p}=0.004)$ (Table 4).

Moreover, the duration of prophylaxis decreased during the post intervention period, with an increase of PAP discontinuation within $24 \mathrm{~h}$, from $83 / 202$ (45.1\%) in the pre-intervention period to $102 / 153(66.7 \%)(<0.001)$ (Table 4).

The stratification of the population by type and characteristics of the surgical procedures showed how CP was significantly effective especially for emergency procedures and for all surgical procedures involving head/ neck and thorax (Table 5).

SSIs rate assessment showed no difference between the two analyzed periods (10/394 (2.5\%) in pre- vs $7 / 372$ $(1.9 \%)$ in post).

\section{Discussion}

Perioperative antibiotic prophylaxis is the most effective intervention to prevent SSIs [1]. The most recent guidelines [9] define procedures requiring PAP, recommending narrow spectrum antibiotics as first choice for less than $24 \mathrm{~h}$ for all procedures (with the exception of cardiac surgery). So far, few studies developed an antimicrobial stewardship program to improve antibiotic prescriptions on PAP in children. Three of these studies showed an improvement of antimicrobial prescriptions after the implementation of perioperative guidelines [3, 6, 7] while Putnam et al. reported no improvement despite multiple interventions [8].

Despite the availability of consensus guidelines designed to facilitate the appropriate use of PAP, a significant variation in this practice has been found for the most commonly performed operations in pediatric surgery [12].

On 31 January 2017 the CP (Figs. 2, 3, and 4) for PAP was implemented and on the same day, an educational lecture was presented. After the lecture, a pocket card was delivered to all participants.

As reported by the studies above mentioned [3, 6, 7], also in our Centre the compliance to PAP guideline improved after CP implementation. Correct PAP significantly increased from 48.9 to $60.1 \%$, with a change both in first choice antibiotics and in duration of prophylaxis.

The choice of correct monotherapy accounted for $81 \%$ in pre-intervention period reaching $91.9 \%$ after CP implementation. Cefazolin, the most prescribed antibiotic in both periods, definitely became the first choice in post-intervention period with a concomitant decrease of ampicillin/sulbactam. This change affected especially head/neck and thorax procedures, where ampicillin/sulbactam was the drug of choice before the intervention. Indeed, PAP CP recommends cefazolin as the first-line antibiotic for all the procedures due to its activity against S. aureus (MSSA) and Gram-negative bacteria, its narrow-spectrum and its low cost. Ampicillin/sulbactam should be considered an alternative only for its broader spectrum [9].

Moreover, the use of correct combination therapy increased. Again, an important contribution was given by the reduction of ampicillin/sulbactam prescriptions especially in association with metronidazole. Indeed, this combination should be avoided due to their overlapping spectrum of activity against anaerobic bacteria. In the post intervention period, the combination of choice was cefazolin and metronidazole. Also the number of patients with a PAP discontinued within $24 \mathrm{~h}$ increased 
Table 3 Correct PAP and most prescribed antibiotics in pre- and post- intervention period

\begin{tabular}{llll}
\hline & $\begin{array}{l}\text { Pre-intervention } \\
(\mathrm{n}=184)\end{array}$ & $\begin{array}{l}\text { Post-intervention } \\
(\mathrm{n}=153)\end{array}$ & p-value \\
\hline $\begin{array}{l}\text { Correct PAPa } \\
\text { Yes }\end{array}$ & $90(48.9 \%)$ & $93(60.1 \%)$ & 0.03 \\
No & $94(51.1 \%)$ & $60(39.2 \%)$ & 0.03 \\
Antibiotic & & & $146(60.1 \%)$ \\
$\quad$ Cefazolin & $145(78.8 \%)$ & $35(22.9 \%)$ & 0.0001 \\
Metronidazole & $45(24.5 \%)$ & $19(12.4 \%)$ & 0.99 \\
Amoxicillin/clavulanic acid & $35(19 \%)$ & $9(5.4 \%)$ & 0.36 \\
Ampicillin/sulbactam & $37(20.1 \%)$ & $6(3.6 \%)$ & 0.0003 \\
Other & $7(3.5 \%)$ & 0.7 \\
\hline
\end{tabular}

aPAP is considered correct when administered as recommended by guidelines both in terms of type of antibiotic and duration of administration

from 83/202 (45.1\%) in pre-intervention period to 102 $(66.7 \%)$ in post-intervention period.

The procedures which have benefitted the most from the intervention were emergency procedures. Usually, patients who undergo emergency surgical evaluation are a severely ill and for this reason surgeons are more prone to exceed the $24 \mathrm{~h}$. Indeed, this represents one of the most difficult points of implementation for an antimicrobial stewardship program. Many are the barriers identified in stopping PAP, the most common being the complexity and duration of surgical procedure, diagnostic uncertainty, inexperienced clinicians, extended in-hospital stay, patient preferences and the fear of SSIs are the most common $[3,13]$. The persistence of urinary catheter represents another point of discussion. Even though all the guidelines recommend stopping PAP despite the presence of a urinary catheter, many surgeons are still reluctant. This could be the reason why we have not seen, for urologic procedures, the same improvement we have seen for others. Moreover, many of the current guidelines and specialty-specific recommendations for the pediatric population are based on adult clinical data. It is possible that physicians may not find those guidelines relevant to their pediatric patients.
Finally, confusion may exist when indication from adult guidelines are not in line with pediatric observational studies (e.g. inguinal hernia repair) [13].

For a further improvement in PAP compliance rate some authors suggested to enforce guidelines' effect with and periodic audit by a surgeon trained in antimicrobial stewardship [3]. This physician would monitor the choice, time and dose of PAP administration and would ensure the guidelines adherence.

Moreover, Prado et al. [14] demonstrated how a hospital pharmacist could have a key role, participating in education activities as part of the discussion groups and in managerial actions that optimized the process of ordering, dispensing, administering, and documenting the perioperative antibiotic prophylaxis.

Despite the higher use of narrow-spectrum antibiotic for fewer days, there was no increase in treatment failures between the two analyzed periods.

This study has strengths and limitations. This is the first study that evaluates the effectiveness of antimicrobial stewardship through clinical pathways in an Italian hospital. This intervention was designed to be feasible, generalizable and was developed by a multidisciplinary team to guarantee the best quality and a high level of coordination of interventions.

Table 4 Choice of antibiotic for PAP and time of discontinuation of antibiotics after surgical procedure

\begin{tabular}{|c|c|c|c|}
\hline Choice of antibiotic for PAPa & $\begin{array}{l}\text { Pre-intervention } \\
(n=184)\end{array}$ & $\begin{array}{l}\text { Post-intervention } \\
(n=153)\end{array}$ & $p$-value \\
\hline Monotherapy & $n=137$ & $n=124$ & \\
\hline Correct & $111(81 \%)$ & $114(91.9 \%)$ & 0.02 \\
\hline Not correct & $26(19 \%)$ & $10(8.1 \%)$ & 0.02 \\
\hline Combination therapy & $n=47$ & $n=29$ & \\
\hline Correct & $31(65.9 \%)$ & $29(100 \%)$ & 0.004 \\
\hline Not correct & $16(34 \%)$ & $0(0 \%)$ & 0.004 \\
\hline Discontinuation within $24 \mathrm{~h}$ & $n=184$ & $n=153$ & \\
\hline Yes & $83(45.1 \%)$ & $102(66.7 \%)$ & $<0.001$ \\
\hline No & $101(54.9 \%)$ & 51 (33.3\%) & $<0.001$ \\
\hline
\end{tabular}

a choice of monotherapy versus combination therapy was considered correct according to the guidelines' recommendations 
Table 5 PAP Stratification by wound class and by type of procedure

\begin{tabular}{llll}
\hline & $\begin{array}{l}\text { Pre-intervention } \\
(\mathrm{n}=90)\end{array}$ & $\begin{array}{l}\text { Post-intervention } \\
(\mathrm{n}=93)\end{array}$ & $p$-value \\
\hline $\begin{array}{lll}\text { Wound class } \\
\text { Clean (C) }\end{array}$ & $48(53.3 \%)$ & $57(61.2 \%)$ & \\
$\begin{array}{l}\text { Clean-Contaminated } \\
\text { (CC) }\end{array}$ & $24(26.6 \%)$ & $22(24.4 \%)$ & \\
Contaminated (CO) & $18(20 \%)$ & $14(15.4 \%)$ & \\
Dirty-Infected (D) & $0(0 \%)$ & $0(0 \%)$ & \\
Emergency procedure & & & \\
Yes & $8(8.8 \%)$ & $21(22.5 \%)$ & 0.02 \\
No & $82(91.2 \%)$ & $71(77.5 \%)$ & 0.02 \\
Type of procedure & & & \\
Appendectomy & $16(17.7 \%)$ & $16(17.2 \%)$ & 0.9 \\
Gastrointestinal/ & $24(26.6 \%)$ & $16(17.2 \%)$ & 0.12 \\
liver-biliary tract & & & \\
Head and neck & $2(2.2 \%)$ & $10(10.7 \%)$ & 0.2 \\
Inguinal / scrotum & $10(11.1 \%)$ & $5(5.3 \%)$ & 0.15 \\
Paediatric Gynaecology & $1(1.1 \%)$ & $4(4.3 \%)$ & 0.18 \\
Skin/soft tissue & $11(12.2 \%)$ & $9(9.6 \%)$ & 0.75 \\
Thoracic & $1(1.1 \%)$ & $9(9.6 \%)$ & 0.03 \\
Urologic & $6(6.6 \%)$ & $7(7.5 \%)$ & 0.95 \\
Other & $19(21.1 \%)$ & $17(18.2 \%)$ & 0.93 \\
\hline
\end{tabular}

The primary limitation of our study is the retrospective nature of the analysis. Another limit was the analysis of treatment failure: we collected SSIs information only trough electronic medical records of our centre. Hence, if a patient had been admitted to another one we would miss that information.

\section{Conclusion}

CPs with a proper educational intervention can be a useful tool to improve the choice of first-line antibiotic and the duration of PAP in pediatric patients.

\section{Acknowledgements}

Not applicable.

\section{Funding}

Not applicable.

\section{Availability of data and materials}

The datasets generated and analysed during the current study are available from the corresponding author on reasonable request.

\section{Authors' contributions}

DD was the major contributor in writing the manuscript, DL contributed to data collection and manuscript writing and revision, ELP and GM contributed to data collection, AF contributed to data statistical analysis and interpretation, RL contributed to the manuscript revision, $T Z, P G$ and $C G$ were major cotributors in conception and design. All authors read and approved the final manuscript.

\section{Ethics approval and consent to participate}

All procedures performed in this study were in accordance with the ethical standards of the institutional and national research committee. Informed consent was obtained from all individual participants included in the study.

\section{Consent for publication}

Not applicable.

\section{Competing interests}

The authors declare that they have no competing interests.

\section{Publisher's Note}

Springer Nature remains neutral with regard to jurisdictional claims in published maps and institutional affiliations.

\section{Author details}

${ }^{1}$ Division of Pediatric Infectious Diseases, Department for Woman and Child Health, University of Padua, Padua, Italy. ${ }^{2}$ PENTA Foundation, Padua, Italy. ${ }^{3}$ Infectious and Tropical Diseases Department, University Hospital of Verona, Verona, Italy. ${ }^{4}$ Pediatric Surgery Department, Department for Woman and Child Health, University of Padua, Padua, Italy. ${ }^{5}$ Department for Cardio-Thoracic and Vascular Sciences and Public Health, University of Padua, Padua, Italy. ${ }^{6}$ Division of Infectious Diseases, The Children's Hospital of Philadelphia, Philadelphia, USA. ${ }^{7}$ Padova, Italy.

Received: 30 August 2018 Accepted: 3 January 2019

Published online: 15 January 2019

References

1. Magill SS, Edwards JR, Bamberg W, et al. Multistate point-prevalence survey of health care-associated infections. N Engl J Med. 2014;370(13):1198208Accessed 26 Oct 2017. https://doi.org/10.1056/NEJMoa1306801.

2. Weigelt JA, Lipsky BA, Tabak YP, Derby KG, Kim M, Gupta V. Surgical site infections: causative pathogens and associated outcomes. Am J Infect Control. 2010;38(2):112-20. http://www.sciencedirect.com/science/article/pii/ S0196655309007470. https://doi.org/10.1016/j.ajic.2009.06.010.

3. Dimopoulou A, Kourlaba G, Psarris A, Coffin S, Spoulou V, Zaoutis T. Perioperative antimicrobial prophylaxis in pediatric patients in Greece: compliance with guidelines and impact of an educational intervention. J Pediatr Surg. 2016;51(8):1307-11. http://www.ncbi.nlm.nih.gov/pubmed/ 26711690. https://doi.org/10.1016/j.jpedsurg.2015.11.017.

4. Varik K, Kirsimägi Ü, Värimäe E, Eller M, Lõivukene R, Kübarsepp V. Incidence and risk factors of surgical wound infection in children: a prospective study. Scand J Surg. 2010;99(3):162-6. http://journals.sagepub.com/doi/full/10. 1177/145749691009900311. https://doi.org/10.1177/145749691009900311.

5. Porras-Hernández JD, Vilar-Compte D, Cashat-Cruz M, Ordorica-Flores RM, Bracho-Blanchet E, Avila C. A prospective study of surgical site infections in a pediatric hospital in Mexico City. Am J Infect Control. 2003;31(5):302-8.

6. So JP, Aleem IS, Tsang DS, Matlow AG, Wright JG, SickKids Surgical Site Infection Task Force. Increasing compliance with an antibiotic prophylaxis guideline to prevent pediatric surgical site infection: before and after study. Ann Surg. 2015;262(2):403-8. https://doi.org/10.1097/SLA.0000000000000934 PubMed PMID: 25423065.

7. Caruso TJ, Wang E, Schwenk HT, Scheinker D, Yeverino C, Tweedy M, Maheru M, Sharek PJ. A quality improvement initiative to optimize dosing of surgical antimicrobial prophylaxis. Paediatr Anaesth. 2017;27(7):702-10. https://doi.org/10.1111/pan.13137 Epub 2017 Mar 21. PubMed PMID: 28321988.

8. Putnam LR, Chang CM, Rogers NB, Podolnick JM, Sakhuja S, Matusczcak M, Austin MT, Kao LS, Lally KP, Tsao K. Adherence to surgical antibiotic prophylaxis remains a challenge despite multifaceted interventions. Surgery. 2015;158(2):413-9. https://doi.org/10.1016/j.surg.2015.04.013 Epub 2015 Jun 6. PubMed PMID: 26054317.

9. Bratzler DW, Dellinger EP, Olsen KM, et al. Clinical practice guidelines for antimicrobial prophylaxis in surgery. Am J Health Syst Pharm. 2013;70(3): 195-283Accessed 12 Nov 2017. https://doi.org/10.2146/ajhp120568.

10. Wilson W, Taubert KA, Gewitz M, et al. Prevention of infective endocarditis: guidelines from the american heart association. J Am Dent Assoc. 2007; 138(6):739-60. https://doi.org/10.14219/jada.archive.2007.0262.

11. Devaney L, Rowell KS. Improving surgical wound classification--why it matters. AORN J. 2004;80(2):208-9 212-23. PubMed PMID: 15382594. 
12. Kato Y. Effects of controlled perioperative antimicrobial prophylaxis on infectious outcomes in pediatric cardiac surgery. Crit Care Med. 2007;35(7): 1763-8. http://www.ncbi.nlm.nih.gov/pubmed/17507823. https://doi.org/10. 1097/01.CCM.0000269027.50834.FE.

13. Rangel SJ, Fung M, Graham DA, Ma L, Nelson CP, Sandora TJ. Recent trends in the use of antibiotic prophylaxis in pediatric surgery. J Pediatr Surg. 2011; 46(2):366-71. https://doi.org/10.1016/j.jpedsurg.2010.11.016 PubMed PMID: 21292089.

14. Prado MAMB, Lima MPJS, HG I d R, Bergsten-Mendes G. The implementation of a surgical antibiotic prophylaxis program: the pivotal contribution of the hospital pharmacy. Am J Infect Control. 2002;30(1):4956. http://www.sciencedirect.com/science/article/pii/S019665530224969X. Accessed 20 Nov 2017. https://doi.org/10.1067/mic.2002.118409.

Ready to submit your research? Choose BMC and benefit from:

- fast, convenient online submission

- thorough peer review by experienced researchers in your field

- rapid publication on acceptance

- support for research data, including large and complex data types

- gold Open Access which fosters wider collaboration and increased citations

- maximum visibility for your research: over $100 \mathrm{M}$ website views per year

At $\mathrm{BMC}$, research is always in progress.

Learn more biomedcentral.com/submissions 